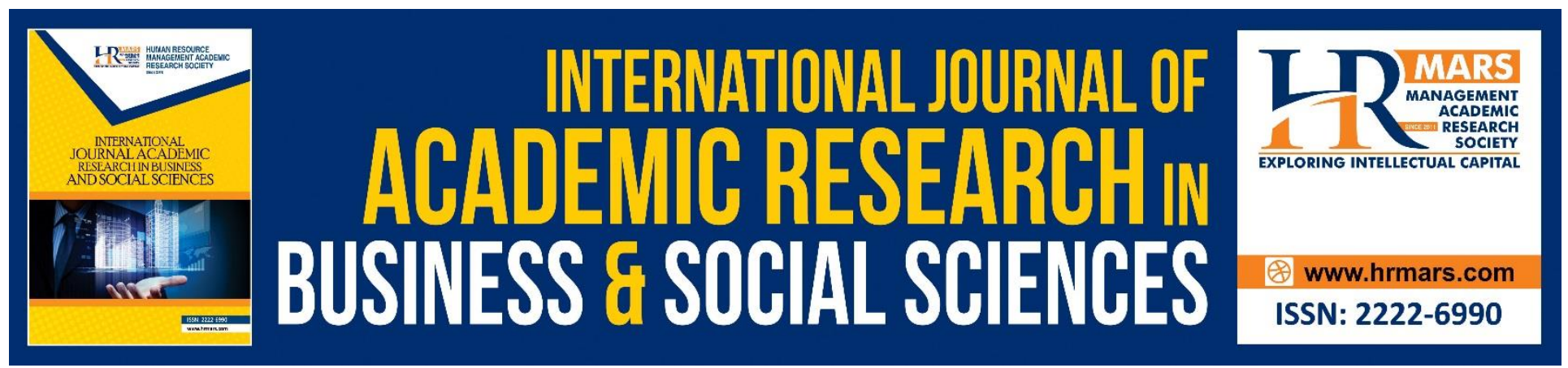

\title{
Hierarchy of Multicultural Criteria among Public University Students in Malaysia
}

Samsudin Suhaili, Hanifah Mahat, Mohmadisa Hashim, Yazid Saleh, Nasir Nayan, Nur Nadia Lukmanulhakim

To Link this Article: http://dx.doi.org/10.6007/IJARBSS/v9-i5/5880

DOI: $10.6007 /$ IJARBSS/v9-i5/5880

Received: 22 March 2019, Revised: 01 April 2019, Accepted: 28 April 2019

Published Online: 29 May 2019

In-Text Citation:(Suhaili et al., 2019)

To Cite this Article: Suhaili, S., Mahat, H. M., Hashim, M., Saleh, Y., Nayan, N., \& Lukmanulhakim, N. N. (2019). Hierarchy of Multicultural Criteria among Public University Students in Malaysia. International Journal of Academic Research Business and Social Sciences, 9(5), 406-419.

Copyright: (C) 2019 The Author(s)

Published by Human Resource Management Academic Research Society (www.hrmars.com)

This article is published under the Creative Commons Attribution (CC BY 4.0) license. Anyone may reproduce, distribute, translate and create derivative works of this article (for both commercial and non-commercial purposes), subject to full attribution to the original publication and authors. The full terms of this license may be seen at: http://creativecommons.org/licences/by/4.0/legalcode

Vol. 9, No. 5, 2019, Pg. 406 - 419

http://hrmars.com/index.php/pages/detail/IJARBSS

JOURNAL HOMEPAGE

Full Terms \& Conditions of access and use can be found at http://hrmars.com/index.php/pages/detail/publication-ethics 


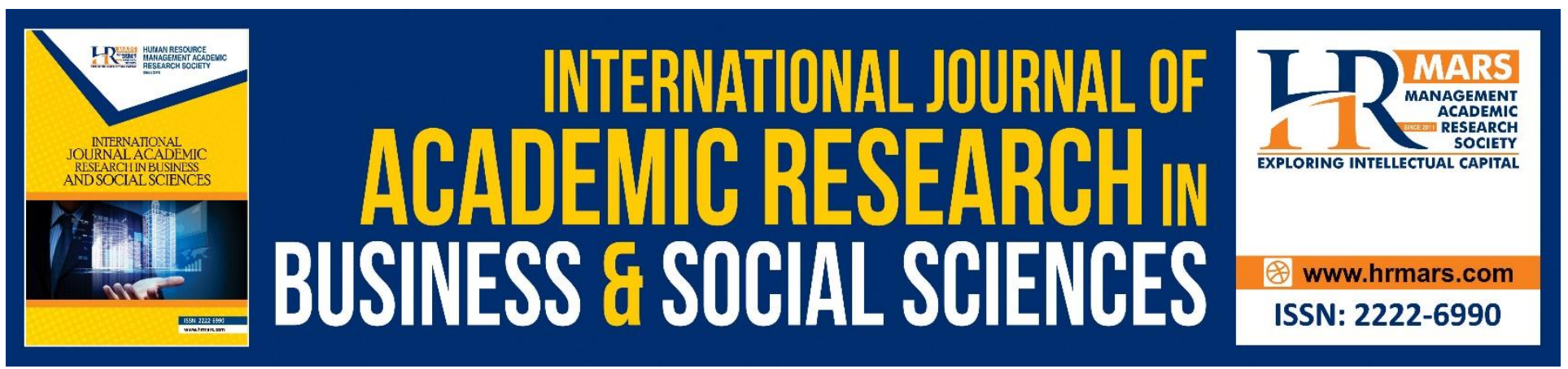

\title{
Hierarchy of Multicultural Criteria among Public University Students in Malaysia
}

\author{
Samsudin Suhaili', Hanifah Mahat ${ }^{2}$, Mohmadisa Hashim², Yazid \\ Saleh$^{2}$, Nasir Nayan ${ }^{2}$, Nur Nadia Lukmanulhakim ${ }^{1}$ \\ ${ }^{1}$ Department of Social Studies and Citizenship, ${ }^{2}$ Department of Geography \& Environment, Faculty \\ of Human Science, Universiti Pendidikan Sultan Idris, Tanjong Malim, Perak, Malaysia \\ Email: samsudin@fsk.upsi.edu.my
}

\begin{abstract}
The article aims to examine the multicultural levels among students in Malaysian public universities based on six multicultural criteria: ethnicity, language, religion, gender, socioeconomic status, and mental and physical capabilities. The study respondents were 330 public university (PU) students who met two requirements for the sample selection, which were having multiple cultural backgrounds and being a student for at least three semesters. The research instrument was a 5-point Likert scale questionnaire consisting of 30 questions related to cultural background. Reliability (Cronbach's alpha) was in the high classification of greater than 0.7. The percentage frequency of the six multicultural criteria also showed diverse responses ranging from "strongly disagree" to "strongly agree." Among the six levels of multicultural criteria, language $(M=3.71, S D=.682)$, gender $(M=3.92, S D=.880)$, and religion $(M=4.34, S D=.617)$ were at high average levels, mental and physical abilities $(M=3.33$, $\mathrm{SD}=.745)$ and ethnicity $(\mathrm{M}=3.57, \mathrm{SD}=.885)$ were at medium levels, and socioeconomic status $(\mathrm{M}=$ $2.44, \mathrm{SD}=.943$ ) was low on average. The correlation between multicultural criteria also showed that each criterion had a strong significant relationship with the other criteria when the correlation coefficient exceeded $0.7(p<0.01)$. Overall, we found that socioeconomic status was still at low levels and should be given attention in the activities at the PU level. The implications of this study could help in designing strategic measures to address the issues among multicultural communities in Malaysia.
\end{abstract}

Keywords: Multicultural, Students, Public University, Ethnicity, Language, Religion, Gender, Socioeconomic Status, Mental and Physical Abilities

\section{Introduction}

Malaysia is well known for its diverse communities with regard to ethnicity, religion, language, and socioeconomic status. Malaysia is no exception in experiencing cultural tensions such as the May 13, 
INTERNATIONAL JOURNAL OF ACADEMIC RESEARCH IN BUSINESS AND SOCIAL SCIENCES Vol. 9, No. 5, May, 2019, E-ISSN: 2222-6990 @ 2019 HRMARS

1969 incident involving fights between individuals of Malaysian, Chinese, and Indian ethnicity (Ahmad, 2007). Consequently, efforts to maintain harmony among the communities of various cultures should continue.

Cultural diversity in Malaysian society needs to be thoroughly studied to achieve the desired unity. Cultural diversity can be summarized with six criteria: ethnicity, religion, language, gender, socioeconomic status, and mental and physical capabilities (Banks \& Banks, 2016). Each of these criteria has its own distinct groups such as the Malaysian, Chinese, and Indian ethnic groups and the Islamic, Buddhist, and Hindu religious groups in Malaysian society.

Cultural preservation by communities of diverse backgrounds in Malaysia is based on the National Culture Policy, which outlined three key principles in the development of Malaysian culture. The first principle states that archipelago cultures are the core of national culture, while the second principle includes other appropriate and reasonably acceptable cultures through a continuous assimilation and adaptation process. In the third principle, Islam is considered an important element in the national religious culture (Ministry of Culture, Malaysia, 1971). Through the three principles outlined in the National Culture Policy, the diverse cultures in Malaysian society have been preserved, making Malaysia a nation rich with a variety of cultures.

The diversity of cultural identity in Malaysia, despite becoming an attraction and unique feature of the country, has made the process of forming a Malaysian nation with one national culture a complicated process. This complicated establishment process occurred because the Malaysian nation as defined by the government had been challenged by several groups in Malaysian society from both Bumiputera or non-Bumiputera, who had their own definitions of a Malaysian nation (Shamsul, 1996). It was evident that the confusion in this regard had led to obstruction of the unifying process of multicultural society in Malaysia under one national culture in the form of different approaches by the groups according to their respective interests. If this process is not carefully handled, the upheaval of society resulting from the failure of establishing one Malaysian nation will cause the country to end up trapped in cultural and identity conflicts.

To aid in managing a multicultural society, a thorough and in-depth study on cultural diversity in Malaysian society is needed. The present study aims to examine cultural diversity by focusing on Malaysian younger generations. We found that there is a cultural diversity hierarchy that could assist in developing strategic measures to address the issues among the people of various cultures in Malaysia.

\section{Literature Review}

The diversity of cultures in Malaysia existed prior to the independence of Malaya (Tanah Melayu) in 1957 and the formation of Malaysia in 1963. Malaya in particular had received various cultures from outside the archipelago through the role of Malacca during the Malacca Malay Sultanate (Kesultanan Melayu Melaka) as an international port (Wilkinson, 1935). The Malacca Malay Sultanate had a close diplomacy relationship with the Chinese government over the role of Malacca as an important port in international trade routes (Watson \& Andaya, 1982).

The relationship that existed between different cultural groups from the time of the Malay Sultanate of Melaka was further added with the change in the Malayan population. From 1870 to 1939, many Chinese individuals entered Malaya due to several factors: the need for a labour force in 
several sectors in Malaya, business and trade opportunities, and the lack of economic opportunities in their homeland (Swee-Hock, 2007). Apart from the influx of Chinese citizens into Malaya, the influx of Indians into Malaya also changed the composition of the Malayan population at the time. The need for a labour force in Malaya resulting from the rapid growth of rubber plantations was the main factor that led to the influx of Indians into Malaya (Leete, 1996). Other factors such as population density in their homeland and natural disasters also affected the migration of Indians to Malaya. The total Indian population in Malaya was reported to have increased from 239,200 in 1911 to 439,200 in 1921 (Chander, 1976).

The formation of Malaysia in 1963 further enhanced the diversity of cultures in the established nation. The Malaysian, Chinese, and Indian populations were later joined by different races and cultures from Sabah and Sarawak. The formation of Malaysia at this point can be regarded as the formation of a nation without a predominant race. The separation of races according to economic activity by the British resulted in the ethnic population pattern according to areas involved in economic activity. Malays were in the rural areas, Indians were in estates or farms, and Chinese were in the urban areas. The British undertook this policy to maintain their economic dominance (Adam, 2003). Following this policy, there was little communication and close interaction to the point that it led to tensions, particularly involving non-Malay ethnic issues in the process of forming the Federation of Malaya (Persekutuan Tanah Melayu) in 1948 (Ramli, 2010). Negotiations between the Malays and non-Malays subsequently produced social contracts that would ensure the harmony of the people in Malaya.

It is evident that British policy caused Malaysia to form without a united society. The diversity of cultures in this country had become a point of overlap between societies in building a stronger and lasting unity. Each group in Malaysian society who felt that their identity had been threatened would take action to reinforce the identity of their respective group (Gudeman, 2002). The identity of the group in this context can be understood in terms of the six categories mentioned above: ethnicity, language, religion, gender, socioeconomic status, and physical and mental abilities (Banks \& Banks, 2016). Cultural diversity became recognised as a natural phenomenon, and each group was given space to maintain their identity, which ultimately became the basis for the formation of Malaysia's national identity.

The interaction and integration processes between multicultural groups in Malaysia have been going on since before Independent Day (1957) through both daily interactions and government policies. However, the level of integration of the Chinese still seemed lower than the Malays (Zahara, Amla, \& Ema, 2010). Although the Community Tension Index in 2013 to 2015 showed a decline, community unity remains the main focus of the government in ensuring that the Malaysian community lives in peace and harmony (Department of National Unity and Integration, 2015). Therefore, in order to create unity in the multicultural society of Malaysia, efforts and strategies need to be constantly updated and modified to meet the content and the current needs of the multicultural society in the country. 
INTERNATIONAL JOURNAL OF ACADEMIC RESEARCH IN BUSINESS AND SOCIAL SCIENCES

Vol. 9, No. 5, May, 2019, E-ISSN: 2222-6990 @ 2019 HRMARS

\section{Method}

Location, Population, and Study Sample

This study was conducted using quantitative methods that involved a questionnaire. The study was carried out on Malaysian Public University (PU) students comprising 20 PUs across Malaysia under the management of the Ministry of Education Malaysia and specifically conducted the policies outlined by the ministry. Sample selection was based on two requirements; the participants needed to have various cultural backgrounds and to be students for at least three semesters. These two requirements were meant to ensure that cultural diversity in Malaysian society was illustrated through the sample of this study and that the selected students had adapted to the atmosphere of the university. Therefore, the sample was selected from students in the PU Student Representative Council in order to comply with this sampling requirement (Table 1).

Table 1. Number of Study Respondents

\begin{tabular}{|c|c|c|c|}
\hline Zone & Universiti Awam (UA) & $\begin{array}{l}\text { Bilangan } \\
\text { Sampel }\end{array}$ & Peratus \\
\hline \multirow[t]{3}{*}{ North Zone } & Universiti Utara Malaysia & 19 & 5.76 \\
\hline & Universiti Malaysia Perlis & 22 & 6.67 \\
\hline & Universiti Sains Malaysia & 20 & 6.06 \\
\hline \multirow[t]{8}{*}{ Middle Zone } & Universiti Pendidikan Sultan Idris & 20 & 6.06 \\
\hline & Universiti Malaya & 17 & 5.15 \\
\hline & $\begin{array}{l}\text { Universiti Pertahanan Nasional } \\
\text { Malaysia }\end{array}$ & 16 & 4.85 \\
\hline & Universiti Teknologi Mara & 25 & 7.58 \\
\hline & Universiti Kebangsaan Malaysia & 26 & 7.88 \\
\hline & Universiti Putra Malaysia & 16 & 4.85 \\
\hline & $\begin{array}{l}\text { Universiti Islam Antarabangsa } \\
\text { Malaysia }\end{array}$ & 17 & 5.15 \\
\hline & Universiti Sains Islam Malaysia & 11 & 3.33 \\
\hline \multirow[t]{3}{*}{ South Zone } & Universiti Teknikal Malaysia Melaka & 14 & 4.24 \\
\hline & Universiti Tun Hussein Onn Malaysia & 5 & 1.52 \\
\hline & Universiti Teknologi Malaysia & 10 & 3.03 \\
\hline \multirow[t]{4}{*}{ East Coast Zone } & Universiti Malaysia Terengganu & 13 & 3.94 \\
\hline & Universiti Sultan Zainal Abidin & 18 & 5.45 \\
\hline & Universiti Malaysia Kelantan & 12 & 3.64 \\
\hline & Universiti Malaysia Pahang & 18 & 5.45 \\
\hline \multirow[t]{2}{*}{ Borneo Zone } & Universiti Malaysia Sarawak & 11 & 3.33 \\
\hline & Universiti Malaysia Sabah & 20 & 6.06 \\
\hline Total & & 330 & 100 \\
\hline
\end{tabular}


INTERNATIONAL JOURNAL OF ACADEMIC RESEARCH IN BUSINESS AND SOCIAL SCIENCES

Vol. 9, No. 5, May, 2019, E-ISSN: 2222-6990 @ 2019 HRMARS

\section{Study Instruments}

The questionnaire was constructed with seven sections. Section A was about the respondents' background. Sections B to $G$ were about the six criteria of various cultures (Banks \& Banks, 2016) including ethnicity, language, religion, gender, socioeconomic status, and mental and physical abilities. Each criterion had five items. Section B measured language, Section C measured socioeconomic status, Section D measured mental and physical abilities, Section E measured gender, Section $\mathrm{F}$ measured religion, and Section $\mathrm{G}$ measured ethnicity (Table 2).

Table 2. Study Instruments

\begin{tabular}{|c|c|c|c|c|}
\hline Section & Description & Variable & $\begin{array}{c}\text { Numbe } \\
\text { r of } \\
\text { item }\end{array}$ & Item Source \\
\hline \multirow{8}{*}{$A$} & & Age & 4 & \multirow{8}{*}{$\begin{array}{l}\text { Self-built according to the needs } \\
\text { of the study }\end{array}$} \\
\hline & & Sex & 2 & \\
\hline & Responden & Ethnic & 4 & \\
\hline & $\mathrm{t}$ & Religion & 5 & \\
\hline & Backgroun & Education Program & 4 & \\
\hline & \multirow[t]{3}{*}{ d } & Field of Study & 8 & \\
\hline & & Semester of Study & 7 & \\
\hline & & Household income & 6 & \\
\hline$B$ & \multicolumn{2}{|c|}{ Language Criteria } & 5 & \multirow{6}{*}{$\begin{array}{l}\text { Built and modified from Banks } \\
\text { and Banks (2016) }\end{array}$} \\
\hline C & \multicolumn{2}{|c|}{ Economic Criteria } & 5 & \\
\hline D & \multicolumn{2}{|c|}{$\begin{array}{l}\text { Mental and Physical Potential } \\
\text { Criteria }\end{array}$} & 5 & \\
\hline$E$ & \multicolumn{2}{|c|}{ Gender Criteria } & 5 & \\
\hline $\mathrm{F}$ & \multicolumn{2}{|c|}{ Religion Criteria } & 5 & \\
\hline G & \multicolumn{2}{|c|}{ Ethnic Criteria } & 5 & \\
\hline
\end{tabular}

As for reliability, the Cronbach's alpha values for all six criteria were between 0.9 and 1 . These values met the minimum Cronbach's alpha value required to indicate that the scale used was reliable, which is 0.7 (Nunnally \& Bernstein, 1994).

\section{Results and Discussion}

Respondents' Background

The respondents were 330 students consisting of 165 males and 165 females and comprising 267 Malays, 26 Chinese, 11 Indians, and 26 individuals of Sabah and Sarawak ethnicity. Of the 330 respondents, 287 were Muslims, 19 were Buddhists, 15 were Christians, and nine were Hindus. Based on the household income fraction, the respondents consisted of the B40 and M40 household income families. Household income B40 is a family with income of RM3000 and below, while the M40 is a family with income of RM6275 and below (Department of Statistics Malaysia, 2017). More than 50\% of respondents were in the $\mathrm{B} 40$ income group (Table 3). 
INTERNATIONAL JOURNAL OF ACADEMIC RESEARCH IN BUSINESS AND SOCIAL SCIENCES

Vol. 9, No. 5, May, 2019, E-ISSN: 2222-6990 @ 2019 HRMARS

Table 3. Respondents' Background

\begin{tabular}{llcc}
\hline Respondents' & Background & N & $\%$ \\
\hline Sex & Men & 165 & 50.0 \\
& Women & 165 & 50.0 \\
Religion & Total & 330 & 100 \\
& Islam & 287 & 87.0 \\
& Buddha & 19 & 5.8 \\
& Christian & 15 & 4.5 \\
& Hindu & 9 & 2.7 \\
Races & Total & 330 & 100 \\
& Malay & 267 & 80.9 \\
& Chinese & 26 & 7.9 \\
& India & 11 & 3.3 \\
& Ethnic Sabah / Sarawak & 26 & 7.9 \\
Household & Total & 330 & 100 \\
income & B40 & 179 & 54.2 \\
& M40 & 151 & 45.8 \\
\hline
\end{tabular}

\section{Multicultural Levels}

Figure 1 shows the percentage of responses for items related to language, which comprised five items. For the first item, "I introduce myself in my native language," the majority of respondents agreed. For the second, third, and fourth items, "I tell others about my native language," "I talk in my mother tongue so my ethnicity is known to others," and "Friends try to learn my native language," the majority of respondents also agreed. But for the fifth item, "Friends do not understand the language I am using," the majority disagreed. 
INTERNATIONAL JOURNAL OF ACADEMIC RESEARCH IN BUSINESS AND SOCIAL SCIENCES

Vol. 9, No. 5, May, 2019, E-ISSN: 2222-6990 (C) 2019 HRMARS

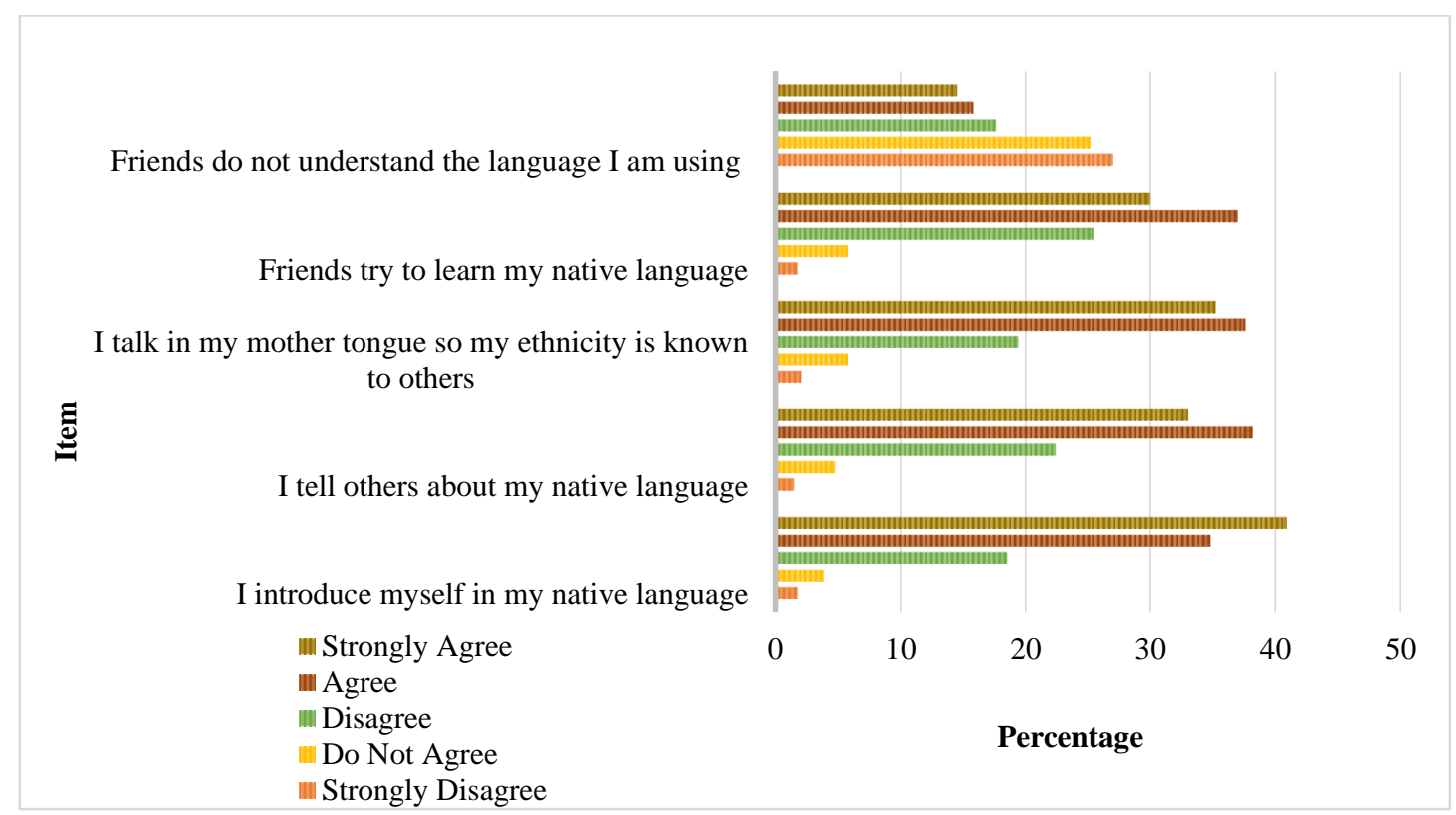

Figure 1. Responses for Multicultural Items related to Language

Figure 2 shows the percentage of responses for items related to economic aspects, which comprised five items. For the first item, "I tell the family's economic background to others," the majority of respondents disagreed. For the second item, "I show the socioeconomic status of the family based on my possessions," the majority of respondents also disagreed. However, for the third, fourth, and fifth items, "I am treated based on socioeconomic status," "My friends know me based on my possessions," and "I am called a wealthy person because of my possessions," the majority strongly disagreed.

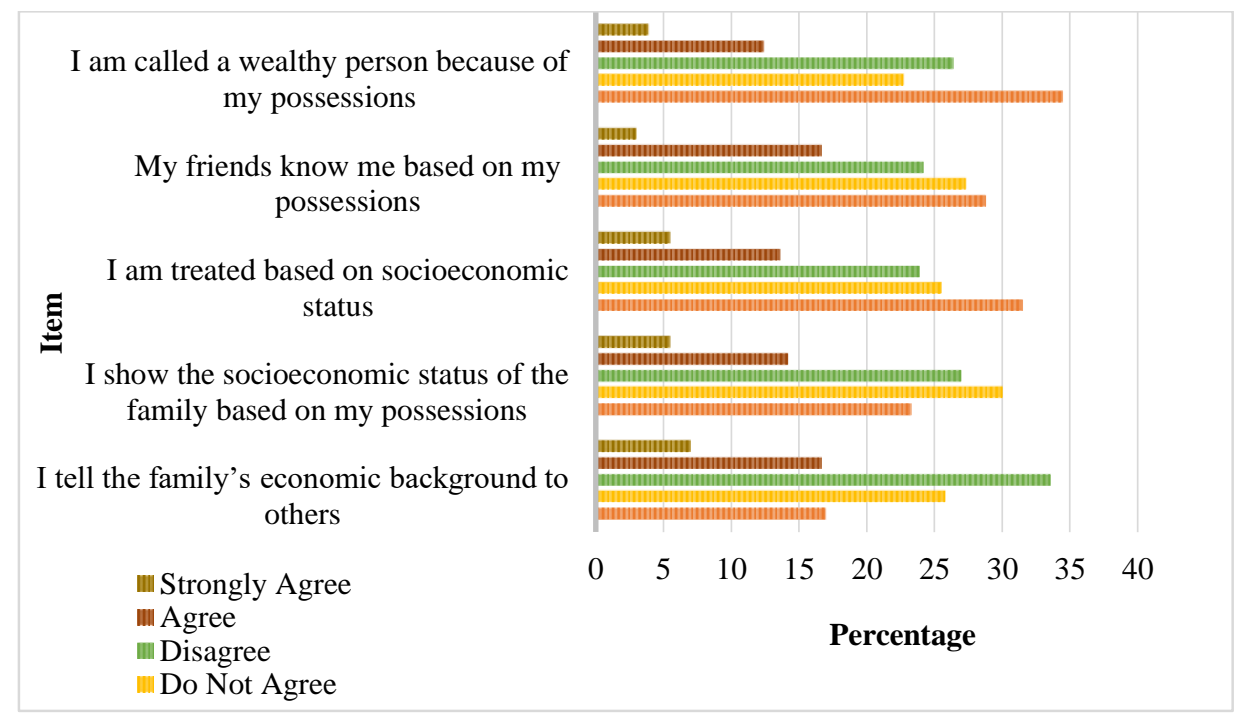

Figure 2. Responses for Multicultural Items related to Economic Aspects 
INTERNATIONAL JOURNAL OF ACADEMIC RESEARCH IN BUSINESS AND SOCIAL SCIENCES Vol. 9, No. 5, May, 2019, E-ISSN: 2222-6990 @ 2019 HRMARS

Figure 3 shows the percentage of responses for items related to mental and physical abilities, which comprised five items. For the first four items, "I introduce myself with mental and physical abilities," "I explain my mental and physical abilities to others," "I am treated based on my mental and physical abilities," and "Friends know me based on mental and physical abilities," the majority of respondents agreed with all four statements. For the fifth item, "Friends do not understand my mental and physical abilities," the majority of respondents disagreed.

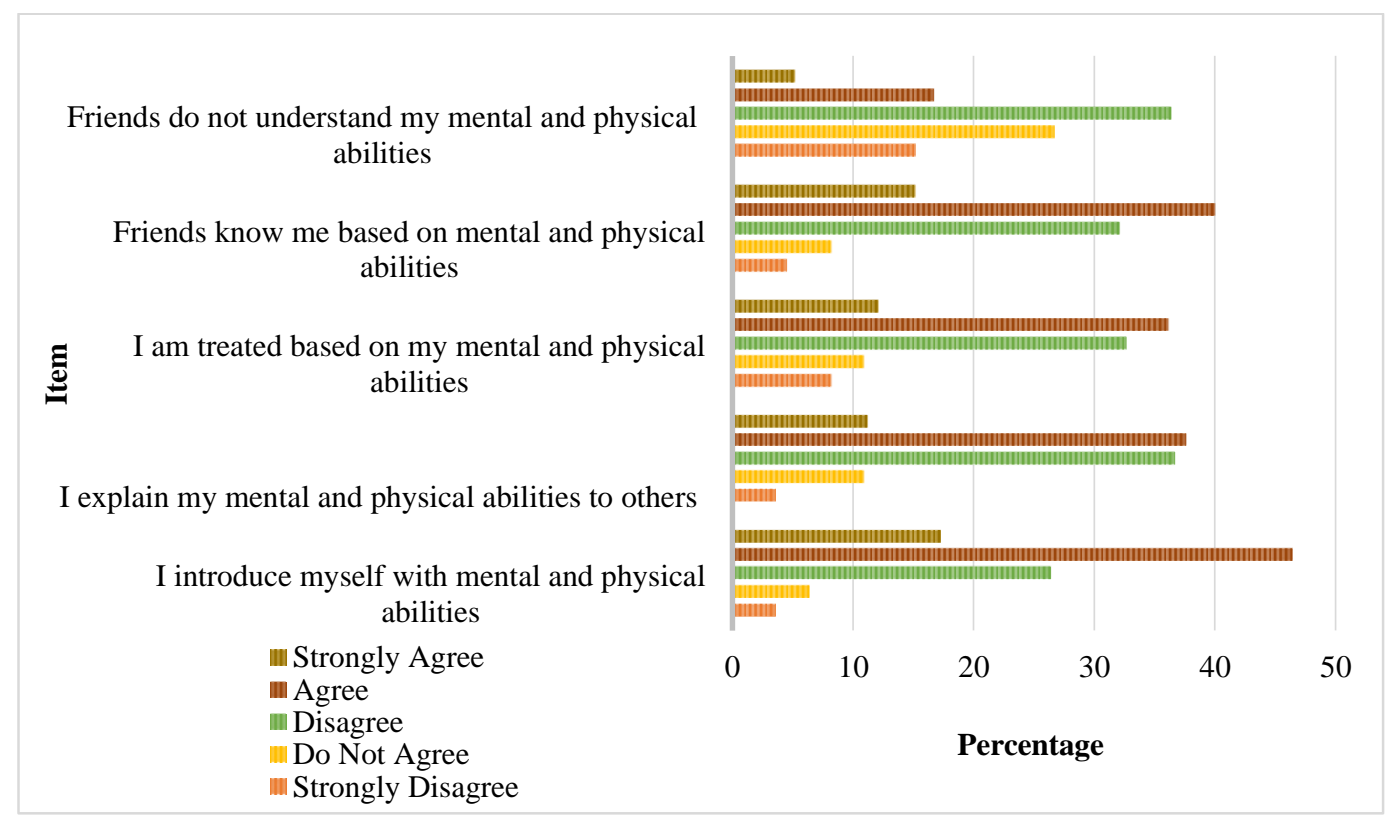

Figure 3. Responses for Multicultural Items related to Mental and Physical Abilities

Figure 4 shows the percentage of responses for items related to gender, which comprised five items. For the first four items, "I choose daily clothing based on gender," "I take care of my appearance due to gender," "I practise gender-based behaviour," and "I am treated based on gender," the majority of respondents strongly agreed with all four statements. For the fifth item, "Friends use voice intonation depending on gender," the majority of respondents only agreed (but not strongly). 
INTERNATIONAL JOURNAL OF ACADEMIC RESEARCH IN BUSINESS AND SOCIAL SCIENCES Vol. 9, No. 5, May, 2019, E-ISSN: 2222-6990 (C) 2019 HRMARS

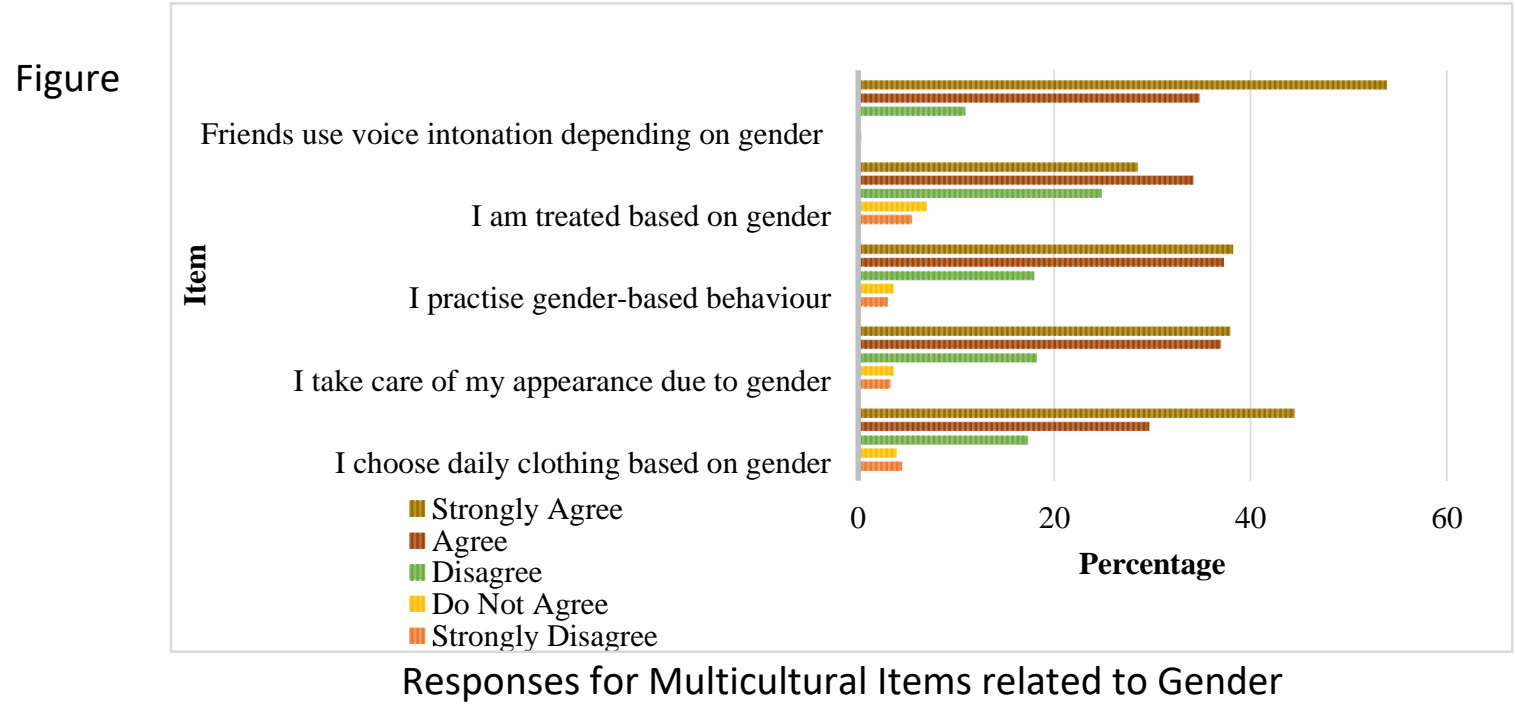

4.

Figure 5 shows the percentage of responses for items related to religion, which comprised five items. For the first four items, "I practise the practices of my religion," "I celebrate the festivals of my religion," "I am behaving based on my religion," and "Friends know what are prohibited in my religion," the majority of respondents strongly agreed with all four statements. For the fifth item, "I am treated by the people around me based on religious background," the majority of respondents only agreed (but not strongly).

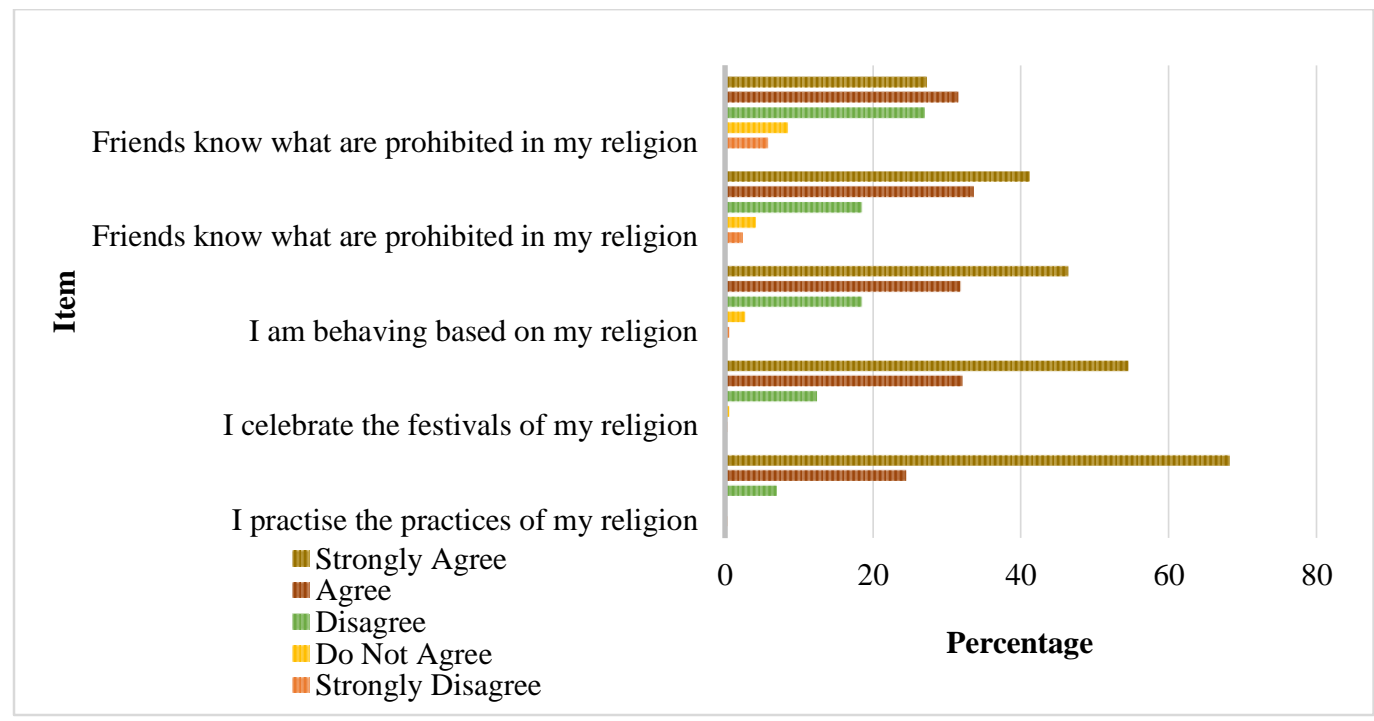

Figure 5. Responses for Multicultural Items related to Religion

Figure 6 shows the percentage of responses for items related to ethnicity, which comprised five items. For the first three items, "I practise the practices of my religion," "I introduce myself by expressing my ethnicity," "I explain about my ethnicity to others," and "I have a deep knowledge about my ethnicity," the majority of respondents agreed with all three statements. For the fourth 
INTERNATIONAL JOURNAL OF ACADEMIC RESEARCH IN BUSINESS AND SOCIAL SCIENCES Vol. 9, No. 5, May, 2019, E-ISSN: 2222-6990 @ 2019 HRMARS

item, "Friends recognise me based on ethnic origin," the majority of respondents disagreed. For the fifth item, "I am treated by people around me based on ethnic background," the majority of respondents strongly agreed.

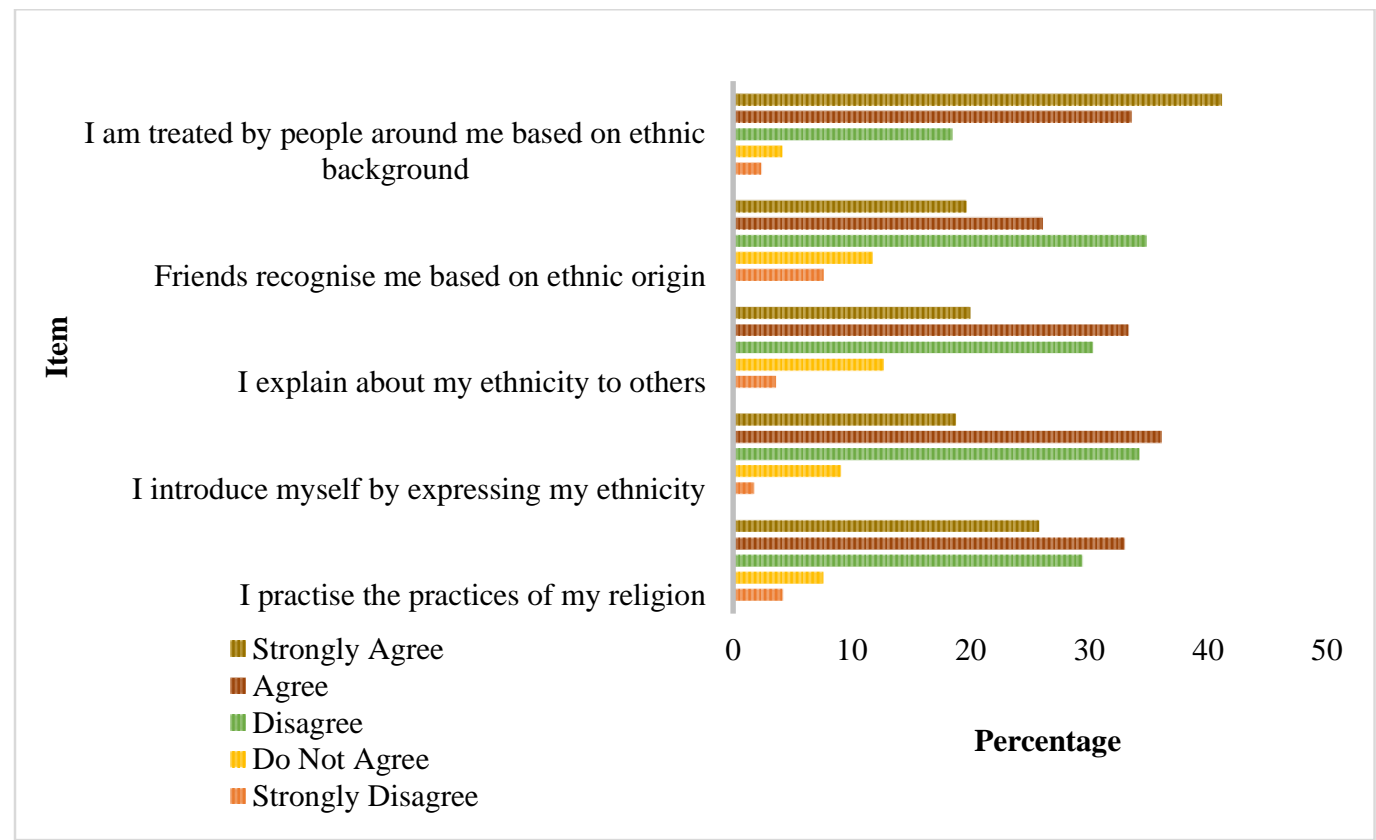

Figure 6. Responses for Multicultural Items related to Ethnicity

\section{Multicultural Levels of Public University Students in Malaysia}

The multicultural levels of public university students in Malaysia were identified by the mean, standard deviation, and level. Level categorisation was based on the scale by Landell (1997) as shown in Table 4. Scores from 1.00 to 2.33 were in the low-level category, scores from 2.34 to 3.66 were in the moderate-level category, and scores from 3.67 to 5.00 were in the high-level category.

Table 4. Cut-off Point of Each Study Variable Level (Landell, 1997)

\begin{tabular}{cc}
\hline Scale & Level of Category \\
\hline Score $1.00-2.33$ & Low \\
Score $2.34-3.66$ & Moderate \\
Score $3.67-5.00$ & High \\
\hline
\end{tabular}

Sumber: Landell, 1997

Table 5 shows the multicultural levels of public university students in Malaysia divided into six criteria (language, socioeconomic status, mental and physical abilities, gender, religion, and ethnicity). The multicultural levels were generally moderate with the overall $\mathrm{M}=3.55$ and $\mathrm{SD}=.509$. The criteria for language $(M=3.71, S D=.682)$, gender $(M=3.92, S D=.880)$, and religion $(M=4.34$, $\mathrm{SD}=.617)$ showed high average levels, while the criteria for mental and physical abilities $(M=3.33$, $\mathrm{SD}=.745)$ and ethnicity $(\mathrm{M}=3.57, \mathrm{SD}=.885)$ showed moderate average levels. The level of the socioeconomic status criterion was low $(M=2.44, S D=.943)$. This indicates that socioeconomic status 
INTERNATIONAL JOURNAL OF ACADEMIC RESEARCH IN BUSINESS AND SOCIAL SCIENCES Vol. 9, No. 5, May, 2019, E-ISSN: 2222-6990 (C) 2019 HRMARS

should be emphasised at the higher education level in line with the concept of human development that emphasises the principles of development and human well-being (Kiky \& Junaenah, 2015).

Table 5. Multicultural Levels of Public University Students in Malaysia

\begin{tabular}{|c|c|c|c|c|c|c|c|c|c|}
\hline \multirow{2}{*}{ Element } & \multicolumn{2}{|c|}{ Low level } & \multicolumn{2}{|c|}{ Simple Level } & \multicolumn{2}{|c|}{ High Level } & \multirow{2}{*}{ Min } & \multirow{2}{*}{ SP } & \multirow{2}{*}{ Mean Level } \\
\hline & $\mathrm{N}$ & $\%$ & $\mathrm{~N}$ & $\%$ & $\mathrm{~N}$ & $\%$ & & & \\
\hline $\begin{array}{l}\text { Overall culture } \\
\text { diversity }\end{array}$ & 4 & 1.2 & 205 & 62.1 & 121 & $\begin{array}{c}36 . \\
7\end{array}$ & 3.55 & .509 & Moderate \\
\hline - Language & 11 & 3.3 & 156 & 47.3 & 163 & $\begin{array}{c}49 . \\
4\end{array}$ & 3.71 & .682 & High \\
\hline $\begin{array}{l}\text { - Socio } \\
\text { economic } \\
\text { status }\end{array}$ & 165 & 50.0 & 132 & 40.0 & 33 & $\begin{array}{c}10 . \\
0\end{array}$ & 2.44 & .943 & Low \\
\hline $\begin{array}{l}\text { - } \text { Mental and } \\
\text { physical } \\
\text { capabilities }\end{array}$ & 26 & 7.9 & 203 & 61.5 & 101 & $\begin{array}{c}30 . \\
6\end{array}$ & 3.33 & .745 & Moderate \\
\hline - Gender & 15 & 4.5 & 105 & 31.8 & 210 & $\begin{array}{c}63 . \\
6\end{array}$ & 3.92 & .880 & High \\
\hline - Religion & 1 & 0.3 & 49 & 14.8 & 280 & $\begin{array}{c}84 . \\
8\end{array}$ & 4.34 & .617 & High \\
\hline - Ethnic & 30 & 9.1 & 145 & 43.9 & 155 & $\begin{array}{c}47 . \\
0\end{array}$ & 3.57 & .885 & Moderate \\
\hline
\end{tabular}

Correlational relationships between Multicultural Criteria

Correlational relationships between multicultural criteria were classified according to the strength of relationship (Cohen, 1988), which can be interpreted in three categories: weak $(0.10<r<0.29)$, moderate $(0.30<r<0.49)$, and high $(0.50<r<1.0$; Table 6$)$.

Table 6. Classification of Relationship/Correlation Strength (Cohen, 1988)

\begin{tabular}{cc}
\hline$r$ Value & Relationship Interpretation \\
\hline $0.10-0.29$ & Weak \\
$0.30-0.49$ & Moderate \\
$0.50-1.0$ & Strong \\
\hline
\end{tabular}

Where $+1.00<r<-1.00$

Source: Cohen (1988) 
Table 7 shows the correlations between the multicultural criteria of language, socioeconomic status, mental and physical abilities, gender, and religion. Overall, the table shows that each of the criteria has a strong significant relationship between the other criteria, as the value of r exceeds 0.7 $(p<0.01)$. This shows that cultural diversity is interconnected between ethnicity, religion, language, gender, socioeconomic status, and mental and physical abilities (Banks \& Banks, 2016).

Table 7. Correlational Relationships between Multicultural Criteria ( ${ }^{*} p<0.01$ )

\begin{tabular}{|c|c|c|c|c|c|c|c|c|c|c|}
\hline \multirow[t]{2}{*}{ Variables } & \multicolumn{2}{|c|}{$\begin{array}{l}\text { Socio } \\
\text { economic } \\
\text { status }\end{array}$} & \multicolumn{2}{|c|}{$\begin{array}{c}\text { Mental and } \\
\text { physical } \\
\text { abilities }\end{array}$} & \multicolumn{2}{|c|}{ Gender } & \multicolumn{2}{|c|}{ Religion } & \multicolumn{2}{|c|}{ Ethnic } \\
\hline & $r$ & $p$ & $r$ & $p$ & $r$ & $p$ & $r$ & $p$ & $r$ & $p$ \\
\hline Language & .871 & .000 & $.803^{* *}$ & .000 & $.810^{* *}$ & .000 & $.816^{* *}$ & .000 & .804 & .000 \\
\hline $\begin{array}{l}\text { Socio } \\
\text { economic } \\
\text { status }\end{array}$ & & & $.837^{* *}$ & .000 & $817^{* *}$ & .000 & $.833^{* *}$ & .000 & .787 & .000 \\
\hline $\begin{array}{l}\text { Mental } \\
\text { and } \\
\text { physical } \\
\text { abilities }\end{array}$ & & & & & $.876^{* *}$ & .000 & $.801^{* *}$ & .000 & .756 & .000 \\
\hline Gender & & & & & & & $.837^{* *}$ & .000 & $\begin{array}{c}.795 \\
* *\end{array}$ & .000 \\
\hline Religion & & & & & & & & & $\underset{* *}{.888}$ & .000 \\
\hline
\end{tabular}

$* *$ significant at $\mathrm{p}<0.01$

\section{Conclusion}

Overall, we can conclude that the percentage frequency of the six multicultural criteria showed that there was a diversity of responses ranging from "strongly disagree" to "strongly agree" for the aspects of language, socioeconomic status, mental and physical abilities, gender, religion, and ethnicity. The multicultural levels of Public University students in Malaysia for these six criteria indicate that the language, gender, and religion criteria were at high average levels, while the criteria for mental and physical abilities and ethnicity were at moderate average levels. However, the socioeconomic status criterion was at a low average level, therefore this element needs to be emphasized and given greater attention.

The findings of this study could help with the design of strategic measures to address the issues among the diverse cultural societies in Malaysia, beginning with the youths who are pursuing their education at higher learning institutions. In order to thoroughly examine the multicultural problems, suggestion to further studies should be conducted involving minority ethnic groups within Malaysia such as the Chinese, Indians, Sabah, and Sarawak. There are few studies focusing on cultural diversity problems faced by minority groups within Malaysia and cultural changes that are taking place in today's Malaysian society. In order to make Malaysia a prosperous and peaceful country, continuous 
INTERNATIONAL JOURNAL OF ACADEMIC RESEARCH IN BUSINESS AND SOCIAL SCIENCES

Vol. 9, No. 5, May, 2019, E-ISSN: 2222-6990 @ 2019 HRMARS

efforts from all parties, either from societies or the government, are necessary. Cooperation between all parties is important in forming a unified Malaysian nation with citizens who have a deep love for the country.

\section{Acknowledgements}

This study was conducted with the help of University Research Grant Top Down (GPU 2016-0237106-41). We give the highest gratitude to Universiti Pendidikan Sultan Idris for providing the research funding.

\section{References}

Adam, A. (2003). Kebudayaan Nasional Sebagai Teras Identiti Kebangsaan - Dari Perspektif Sejarah. In B. Shamsul Amri, A. A. Rahimah, E. Abdul Rahman, I. Mohamed Yusof, \& M. S. Kamaruddin (Eds.), Membina Bangsa Malaysia Jilid 2: Identiti Nasional. Bangi. (In Malay)

Banks, J. A., \& Banks, C. A. M. (2016). Multicultural Education: Issues and Perspectives (9th. ed.). United States: Wiley.

Chander, R. (1976). 1970 General Report: Population Census of Malaysia. Kuala Lumpur.

Cohen, L. \& Manion, L. (1989). Research methods in education (3rd. ed.). London: Routledge.

Gudeman, R. H. (2002). Multiculturalism in Malaysia: Individual Harmony, Group Tension. Macalester International, 12.

Kiky, K. A. \& Junaenah, S. (2015). Kemunduran sosioekonomi dan penyisihan sosial komuniti Bumiputera di Bandaraya Kuching: Kajian kes di Kampung Kudei Baru dan Kampung Sinar Budi Baru Batu Kawa. Geografia, 11(13), 131 - 14. (In Malay)

Jabatan Perpaduan Negara dan Integrasi Nasional. (2015). Indeks Ketegangan Masyarakat Suku Tahun 2013-2015. (In Malay)

Kebudayaan, K., Pelancongan, K, D. (1971). Dasar Kebudayaan Kebangsaan. Pejabat Perdana Menteri Malaysia.

Landell, K. (1997). Management by Menu. London: Wiley \& Sons Inc.

Leete, R. (1996). Malaysia's Demographic Transition: Rapid Development, Culture, and Politics. New York: Oxford University Press.

Nunnally, J. C. \& Bernstein, I. H. (1994). Psychometric Theory (Third). New York: Mcgraw-Hill, Inc.

Ramli, A. H. (2010). Perdebatan antara kaum mengenai isu kerakyatan sebelum merdeka. Jurnal Sejarah, 18, 55-86. (In Malay)

Shamsul, A. B. (1996). Nations-of-Intent in Malaysia. Dalam S. Tonnesson \& H. Antlov (Eds.), Asian Forms of the Nation (pp. 323-347). London: Cruzor.

Swee-Hock, S. (2007). The Population of Malaysia. Singapore: Institute of Southeast Asian Studies. Watson, B. \& Andaya, L. Y. (1982). A History of Malaysia. London: Macmillan Education.

Wilkinson, R. J. (1935). The Malacca Sultanate. Journal of the Malayan Branch of the Royal Asiatic Society, 13(2), 22-67.

Zahara, A., Amla, S. \& Hardiana, E. R. (2010). A study of national integration: Impact of multicultural values. Procedia - Social and Behavioral Sciences, 7(2), 691-700. Retrieved from https://doi.org/10.1016/j.sbspro.2010.10.094 